\title{
NARRATION AS A MEANS OF COMMUNICATION IN SELECTED NOVELS BY J. M. COETZEE: WAITING FOR THE BARBARIANS AND FOE
}

\author{
Jihad Jaafar Waham ${ }^{1}$, Wan Mazlini Othoman ${ }^{2}$ \\ 1, 2Department of English Language and Literature \\ Faculty of Languages and Communication \\ University Pendidikan Sultan Idris (UPSI), \\ Tanjong Malim Perak Darul Ridzuan, Malaysia. \\ E-mail: jihadalnashi@gmail.com
}

Received: 27 May 2019

Accepted: 15 November 2019

\begin{abstract}
Narrations become very important such that we tend to try to make others want to fit into them to identify with us, which is why narrative is often used in the recount of events, the past, geared to justify the systems of domination and control evident in the plight of South Africans during the apartheid period. Moreover, narrative also shelters realities against which the truth can be judged, and they also have some sense or measure of a proper world order, against which moral action can be judged. As such, narration point of view can also be determined through the perspective of the story being told. Be it the first person narrative where the author or narrator refers to himself with the personal pronouns I, me, my, and myself. However, this mode of narration may also use second and thirdperson pronouns. Therefore, the second Person narrator sees the author or narrator addresses the reader directly as you, and may use the words we and $u s$ as well in the process. The third person pronouns still could be used in such a novel, where the narrator or author refrains from using first or second person and only refers to characters as he or she or it to demonstrate his narrative techniques in this process. To this effect narrative techniques employed by J. M. Coetzee's as accounted in the selected novels used for this paperwork to explore Coetzee's capabilities to develop a true sense of self as well as to communicate to others through the narration
\end{abstract}

Keywords: narration, communication, narrative technique

\section{Introduction}

According to Seifzadeh and Raju (2014) narrative is described as a series or sequences of events and the word story may be used as a synonym of narrative. Ricoeur (2010) postulates that the identity of a story is made up from the character; and on the pretext, narrative technique is a medium through which a writer uses it as a gear to present the major and minor characters of the story. Thus, the author's choice of narrative techniques will go a long way to determine the theme of the fictional work, and this is one of the main reasons why voice and cultural appropriation are hugely linked to narrative technique. A writer's projection of his narrative devices will be well able to speak on behalf of the protagonist, if 
the adaptation techniques are right, accurate and direct to the point. Thus, there will be a good vice appropriation; otherwise, misunderstanding of categories like culture, caste, and gender might take place. As such, misappropriation and recognition are the result of misunderstanding and a pathetic observation of the subject and culture (Ricoeur, 2010).

\section{Literature Review}

The narration perspective is coined into the words narratology. According to Landa and Onega (2014), narratology has proven to be a source of many key concepts and analytical tools which have increasingly been applied and used in the study of a wide variety of texts, in the general sense of the word (Landa and Onega, 2014). Narratology has evolved into a multi-disciplinary study of narration and the ability to negotiate and incorporate insights of other critical discourses has made it applicable to the analysis of both literary and nonliterary genres, as well as texts which need not be defined as strictly narrative. Therefore, a narrator is the person who tells the story and the story is told from his or her point of view and basically on experience or witness for credibility. More often than not, the narrator is basically a voice that tells the story in the third person singular perspective, perhaps, someone. We, the readers might not know who takes no part in the story as well. Such type of narrator has no personality but processes of power to know the minds and hearts of characters in the novel itself.

On the other hand, a third person narrator knows everything about the characters and events in the novel, whereby, they can follow characters into their comforts and perhaps into their thoughts, and are well present to describe events that take place. In some instance the narrator has the voice of the author and may comment on the action of the characters in the novel, and may even speak directly to the reader (Landa and Onega, 2014). Significantly, third person narrator tells the story from the point of view of one of the main characters in the novel. Thus, the narrator can or may also be able to see into the minds and thoughts of all the characters through which the main character tells their own story in their own words. Furthermore, when the narrator tells the story through the eyes of the main character, this may well be known as the first person narrator. The first person narrator consequently reports on the main character's thoughts and feelings as well as their actions and reactions.

Furthermore, narratives in the form of stories and accounts to make sense of the world in regards to occurrence and experience around them play multitudes of roles within human life and experience as a whole as readers and audiences alike have come to appreciate such types of stories. These stories in many cases allow the readers to rope together meanings, make connections, draw distinctions, construct a sense of which they are, differentiate them from others, shape and maintain their memories, draw maps of different social status and power, provide ultimate meanings to the world, and mold them in a series of ways.

Daniel, cited in Baker (2016), suggested that the human mind can be seen as vast, complex, story-writing machines as such, narration do not have equal value because most people unconsciously choose some really enormous stories that they accept both as true insofar as they make a multitude of decisions in relation to such stories, as foundational insofar as they also provide a kind of background story to all the other stories that tells about their lives. Thus, narrations are bigger stories that allow human beings to make ultimate sense of the world they live in today. The evolution of man, civilization, advent of exploration and science, revolution, history and historical facts, theories, perhaps towards absolute old knowledge are well accounted for through the narration. 


\section{Research Method}

This paper is a library research whose main goals are to examine the concept of narration through Coetzee's fictional characters in his selected novels and to analyze how he portrays narration as a means of communication in South Africans depicted in the novels. The data of the present work were derived from two novels Foe and Waiting for the Barbarians. Foe is a story of a woman who was stranded after a shipwreck and subsequently rescued. Upon being rescued she contacts Daniel Foe, a writer to help publish her story. Friday the character in the story is tongueless, silent, marginalized and desires to be liberated. Vividly resistance can be seen in the attitude of Susan, who sets out on a Journey to find her daughter and also resists the temptation of returning Friday back who could possibly be sold as a slave again. The second novel is Waiting for the Barbarians whose main character is the magistrate who is also the chief narrator.

\section{Result and Discussion}

\subsection{Narration and Its Significance in Literary Works}

It is important to note that narrative technique is the logical order of events presented to the readers in a way that allows the author to show his ability and talent in conveying the themes which are expressed within the literary work, be it a novel or a short story. Although there are numerous techniques as seen in various novels or short stories, it is undeniably vital for writers to adapt a specific and unique technique of writing literary works. The writers of fiction generally start with their plan in a framework from which they choose a point of view that contains perspectives to narrate the story. By so doing the choice of point of view, they determine which characters, thoughts, actions, and perhaps feelings that are accessible to the reader. This is because typically in a third person point of view technique or omniscient point of view, the narrator of the story is not a character within the story, but is an authoritative figure to present the events, as well as able to access the thoughts and feelings of all the other characters within the story. The narration is a way of arranging or organizing episodes, actions, and accounts of actions as an achievement that will bring together monotonous facts, fantastic creations, in time and place incorporated to bring out an idea. Narration allows the addition of actors, reasons for their acts, as well as causes of the happening (Seifzadeh and Raju, 2014, Sarbin, 1986).

The manner of sending information to spectators, audiences, and readers is a function of narration which is hugely determined by the narrative technique. Therefore, situation and instances when and where the characters inside a story are created by the author begin to speak at this point. The author employs dialogues through which the characters use to tell their stories. The purpose of the dialogues is to aid the authors in creating scenes through which characters speak to one another and voice their thoughts and feelings. Upon choosing ways in which the author narrates the story and the manner by which the characters can speak, specifying time in which the events of the story take place is equally important to give the story a direction.

Instances where the storyline jumps or tracts backward to show thing that may have happened prior to the main event of the novel, which is relevant to the present story, or even when the writer speaks and remembers some event that may have happened in the past and is important in leading the reader to the central present event, this is viewed and known as a flashback. The author may also use foreshadowing, which is when the narration hints of things that will or may happen, but have not happened yet and this is known as the shifts in time. This is equally important to the process or reading or analyzing a story and 
even before examining the various elements of the story, setting, its significance, main characters, motivation of characters and how other characters relate to them. This helps in the narration process in obtaining the meaning and central idea on the part of the readers and even the authors (Sandelowski, 1991).

\subsection{Drawing Inference from Narrative Character}

The narrative work is the result of a careful articulated plan and the realization of such plan serves as a testament to the author's intention. The author, through the work, makes claims to the truth, facts of occurrence by way of history, awareness morality, or perhaps a warning and in the process may well reveal things in reflecting the author's intentions and how well or otherwise they have been or could be realized. The author creates the narrative idea in an artistic form, as it affects the author as well audience from consciousness (Gare, 2002). Narration is a consciousness mode with multifaceted relationship in forging links and relations between the author, his work, readers and fellow authors as well. According to Rankin (2002) who noted and suggested that the relationship between the narrative work and narrative consciousness is never static, but will always revolve continually over time. Thus, narrative is characterized as communication because its essence as with any acts is either conscious or unconscious intentionality as the case may be. Therefore, humans as the audience, readers and authors alike are also agents in the narration who aid to produce, create and interact with each other using communication in the completion of the narration through acts, speeches and actions.

\section{Foe}

Foe is a story of Susan Barton, a woman stranded after a shipwreck and subsequently rescued. Upon being rescued she contacts Daniel Foe, a writer to help publish her story. Friday the character in the story is tongueless, silent, marginalized and desires to be liberated. Vividly resistance can be seen in the attitude of Susan, who sets out on a Journey to find her daughter and also resists the temptation of returning Friday back who could possibly face being sold as a slave again (Mostafaee, 2016). For instance, Friday in Coetzee's Foe, represents the gap in Susan Barton's narration or story as he is silent and unable to speak which also prevents Susan Barton's story from being told. Unless she penetrates the silence surrounding him, Friday will open his mouth and hear what he will say. Here are Susan's words to Friday in his inability to speak: "It is left for us to open Friday's mouth and hear what it holds to say silence, perhaps, a roar, like that of a seashell held to the ear"'(Foe, 1983, p. 142).

The narrative novel illustrates the perspective of Susan for the fact that Friday does not have a tongue and he is castrated along with the fact that she is uncomfortable in sending him back home for fear of being sold into slavery, which constitutes a communication to readers about the dangers of colonization in Africa and the apartheid regime. Thus, even without words the narration gives description about Friday who communicates a theme or idea to the readers via narration.

In Foe, Susan encounters a number of problems while trying to tell her story, at the same time trying also to form her identity in relation to the memories of her mind and experience and besides this, writing her life story can be viewed as a tale of finding or constructing her true identity. Equally, the difficulties surrounding the representation of the story in general and particularly the representation of Susan's story are very vital in the novel. Ultimately, the search for substance or identity is not very difficult because of the 
structure of the novel. Thus, the novel is structured in parts to which each of the parts are narrated from a different point of view and Foe is supposed to be Susan's voice as she desires to narrate her story, thus making it easy to identify who she is. Furthermore, Susan attempts to fuse her inside experience with the external medium like Friday, a man with a tongue cut off and also castrated. In this regards the establishment of radical difference is visible. Although racial otherness can be figured even though it is not spoken, thus Friday's speechlessness connotes a colonized victim and a means of figuring out otherness racially (Van der Rassel, 2006).

The story of Friday's tongue is a story incapable to be told or unable to be told by me. That is to say, many stories can be told of Friday's tongue, but the proper story is buried within Friday, who is voiceless? The true story will not be heard till by art we can find a means of giving voice to Friday to speak. (Coetzee, 1983: p.118)

The above episode on its own showcases the vital role the narrative plays in the course of literary works as well as account of event in fictional form or reality. Readers might trace the connection between the wreck as explored by the anonymous narrator of part four and the ship that brought Susan and Friday back to England. Furthermore, identification becomes even complex in Foe because that ship never sank down and on a second look, it can also be viewed as a wreck of the ship on which Cruso and Friday had sailed with. The corpse in which the narrator of chapter five tentative talking about could be thought as belonging to the mysterious girl who continually follows Susan and claiming to be her daughter. In description, the body of a woman or a girl described as having unnaturally short limbs and wearing a long gray dress which reminds us of the gray cloak and cape the girl was wearing when she first met with Susan in part two (Caracciolo, 2012).

\section{Waiting for the Barbarians}

Waiting for the Barbarians is narrated in the first person and is very pronounced as opposed to other works of Coetzee. The main character in the novel is the magistrate who also is the chief narrator. The magistrate's narration, in one instance, shifts to an account of a dream to which later on it can be realized that the sequence of images was in fact his recurring dream. Subsequently, the narrative in the novel is largely constructed in the present tense without much mention of names, places, people, and perhaps time even though it is visible to know the era of the writing. This constraint, however, provides the fabric context that allows for universalism. Such a story is told from the point of view of the narrator with a deliberate style, deep, and bare and depriving some details on some parts while using a great and many details on the other. The magistrate's narrative presents tense narration tone, records the present uncertainly without constant drawing retrospective connections to events. Simultaneously, as the events occur, the magistrate tells his story in the present tense without historical aspects present after the facts. Coetzee exercises a great deal of control in the descriptions of events and characters and clearly knows when to release and hold back detail, as well as when to report with great detail so as to make the description effective for readers. Although the contention between Fantasy and Reality has been more elaborately modern fiction, in the Coetzee's case, the act of writing is a medium of self preservation in a vastly politicized society like South Africa (Al-Saidi and Ahmed, 2014).

Much as it appears, sexual exploitation is visible in Coetzee's work, in the case of Writing for the Barbarians between the magistrate and the barbarian girl. Coetzee does not shy 
away from the aspect of sex as a symbol of exploitation and suppression and not only in regards to feminism. Witnessing the public torture of the barbarians by Joll, the magistrate is moved to mount some type of resistance once when a hammer is drawn out for the purpose of breaking the prisoner's feet, a fate suffered by the girl as well. The terror of colonial paranoia is significantly the theme of this book as even the magistrate taking in the young girl blinded by torture also obsessively wishes for her body. Even though he does go a long way to console her too, yet tracing the lines of scars on her skin, and trying to return her to her people across the desert is a resistance to the colonial oppression (Craps, 2007).

The Magistrate, in Waiting for the Barbarians, is primarily the highest colonial representative of the Empire in the barbarian land and the narrative clearly shows the higher officials of the Empire, who arrive and immediately begin interrogating and torturing prisoners. The Magistrate begins considering his role an oppressor, as well and struggles to detach himself from his people's legacy and starts something new. He desperately searches for the truth with the hope that it will help him to define himself and correct the wrongs of the past. However, his passion with it perhaps leads to his downfall with his personal feelings intruding into his scheme of things in his attempt to develop a mutual relationship with a barbarian woman who was also a prisoner of the Empire. He attempted reconciliation with the barbarian girl and changed his identity and his motivation although he failed in finding the truth he was searching for and this lead him to be separated from the hegemony group (Buboltz, 2009).

In Waiting for the Barbarians Colonel Joll an official and member of the Empire's new secret police, also known as the Third Bureau believed that the barbarians were planning an attack on the frontier regions but the magistrate does not believe the rumors of a barbarian threat to the frontier region. This, however, led to inhuman treatment of the locals otherwise known as the barbarian. Thus, a blind girl begging for food in the streets and whose ankles and legs were broken caught the sympathy of the magistrate who took her off the streets and took her to his home. Washing the blind girl's feet and her broken ankles and practically he washes her entire body, and eventually taking care of her. Thus, the narration point of view in this regards communicates to the readers the situation and predicament of the local who were otherwise labeled as barbarian. This further shows the heights of colonialism and its ills on the ways of life of the people and the forceful change to accept the supremacy of the white color. The contemplation and reasoning of the magistrate in his words to the girl simply says, "I'm taking you back to your people, near or as near as much as I can, to see they are now dispersed" (Coetzee, 1980: p. 80).

Waiting for the Barbarian sees identity of the magistrate as a worker for the empire government and as an active participant in the administrative function of the empire. Thus, any reluctance or unwillingness in the machinery of the imperial authority belongs to the prevailing colonial discourse. Although he represents the liberal humanist who tries to maintain a moral gap from foul acts of the group, yet he fails. At least he has done his best by every means available (Coetzee, 1980).

\section{Conclusion}

The method of analyzing the manner in which people make causal connections in order to create coherence in a story is narrative. It refers to the way how a story is told and so it belongs to the level of discourse, although in first person narration the narrator may also plays the role in the development of the story itself. Narration is intended to give meanings to the narrative products through actions, the expression of ideas, criticisms, and feelings in 
the story. There is also conscious and unconscious intention in the act of communicating messages to get respond by speaking to be heard, to connect to others, to interact and to recognize self in actions, to gain recognition from others, as well as to come to some sort of recognition of the intentions of others or even create awareness in the process of such narration as the case may be. Narration in regards to a novel and other types of literary works is a product of an intentional creative act from a narrative consciousness. Therefore, a literary work in terms of fiction may not be possible without the author's resultant purposes, and this is why denial of authorship of a work and the circumstances and the reasons for the publication is equivalent to denying the purpose of the work and its ability to communicate its main ideas. Therefore, there is a connection between the narrative product and the principal consciousness, on the part of the author, staking a claim through which the work and the author are intimately linked in the act of creativity.

\section{References}

Al-Saidi, H. and Ahmed, A. (2014). Post-colonialism Literature the Concept of self and the other in Coetzee's Waiting for the Barbarians: An Analytical Approach. Journal of Language Teaching \& Research, 5(1).

Baker, L. R. (2016). Making sense of ourselves: Self-narratives and personal identity. Phenomenology and the Cognitive Sciences, 15(1), 7-15.

Caracciolo, M. (2012). J. M. Coetzee's Foe and the embodiment of meaning. Journal of Modern Literature, 36 (1), 90-103.

Coetzee, J. M. (1980). Waiting for the Barbarians. London: Penguin Books.

Coetzee, J. M. (1986). Foe. London: Penguin Books.

Craps, S. (2007). J. M. Coetzee's Waiting for the Barbarians and the ethics of testimony. English Studies, 88 (1), 59-66.

Gare, A. (2002). Narratives and culture: The primordial role of stories in human self-creation. Landa, J. A. G., and Onega, S. (2014). Narratology: An introduction. London: Routledge.

Mostafaee, J. (2016). Investigating identity, ambivalence, hybridity: A Bhabhaian reading of J. M. Coetzee's Foe and Disgrace. Advances in Language and Literary Studies, 7 (6), 163-167

Rankin, J. (2002). What is narrative? Ricoeur, Bakhtin, and process approaches concrescence. The Australasian Journal of Process Thought Concrescence, 3, 1-12.

Ricoeur, P. (2010). Time and narrative (Vol. 3). Chicago: University of Chicago Press.

Sandelowski, M. (1991). Telling stories: Narrative approaches in qualitative research. Journal of nursing scholarship, 23(3), 161-166.

Sarbin, T. R. (1986). Narrative psychology: The storied nature of human conduct. Westport Connecticut: Praeger Publishers/Greenwood Publishing Group.

Seifzadeh, N., and Raju, B. Y. (2014). Narrative technique and voice appropriation in selected modern Indian English fiction. International Journal of Research in Humanities, Arts and Literature, 2 (6), 151-156.

Van der Rassel, D. (2006). What is left behind? - The role of Friday in J. M. Coetzee's Foe. Retrieved from: http://www.tijdschriftframe.nl/19-1-diversen/donata-van-der-rasselwhat-is-left-behind-the-role-of-friday-in-j-m-coetzees-foe/ 